\title{
Recognition and Enforcement of Foreign Criminal Judgments under the Law of Somalia
}

Anton Girginov"

A former State Prosecutor and University Professor, PhD, DSc; International Prosecution Adviser in Mogadishu with European Union Capacity Building Mission in Somalia

DOI: $10.36348 /$ SIJLCJ.2019.v02i10.001

| Received: 01.10.2019| Accepted: 08.10.2019| Published: 15.10 .2019

*Corresponding author: Anton Girginov

\section{Abstract}

The recognition and enforcement of foreign criminal judgments is a modality is opposite to the extradition of sentenced parsons for the execution of the punishment imposed on them. This is a traditional modality international judicial cooperation in criminal matters. Although it assists future execution proceedings in the country which has accepted the foreign judgment, this modality is not any part of them. Moreover, it is a specific procedure based on different principles. This procedure is rarely used; its efficiency is low. As a result, it constitutes a serious challenge to both lawmakers and judicial actors (criminal judges, prosecutors, investigators), especially in countries with outdated criminal legislation and weak criminal justice system, such as Somalia. This research paper describes the current situation and resorts to the comparative law approach, mainly. It aims at explaining Somali law on the recognition and enforcement of foreign criminal judgments to eventually, facilitate the process of turning Somalia into a predictable international partner in the common struggle of nations against crime.

Keywords: Foreign criminal judgment, recognition, enforcement, execution, judicial cooperation, international agreement.

Copyright @ 2019: This is an open-access article distributed under the terms of the Creative Commons Attribution license which permits unrestricted use, distribution, and reproduction in any medium for non-commercial use (NonCommercial, or CC-BY-NC) provided the original author and source are credited.

\section{INTRODUCTION}

For many years the opposition to the enforcement of foreign penal law and particularly, to the execution of criminal punishments imposed abroad was absolute. Today, however, this nationalistic resistance to foreign punishments does not exist any longer. Foreign punishments may also be executed if the imposing judgment is recognised and enforced.

Therefore, the recognition and enforcement of a foreign criminal judgment on some incoming request is, actually, a transfer of the execution of such judgments to the requested country. As the transfer of criminal proceedings hands over the legal proceedings for a given crime to another country preserving the admissibility of all evidence collected so far, likewise, therecognition and enforcement of foreign criminal judgments hands over to another country the legal proceedings for the execution of a punishment, which has already been imposed. Unlike the situation with extradition, the person concerned is the requestedcountry, which is expected to receive the proceedings, and the fact that $\mathrm{s} / \mathrm{he}$ is a national of that country can never impede the hand-over.
Somali domestic law regulates incoming requests to Somalia for recognition and enforcement of foreign criminal judgments. Article 10 [Recognition of Foreign Penal Judgments] of the PC establishes the prerequisites while Articles $282-286$ of the CPC established the procedure of this modality of international judicial cooperation in criminal matters.

\section{The Purpose of the Recognition and Enforcement of} Criminal Judgments in another Country

As the transfer of criminal proceedings resembles, differs from and substitutes the extradition for trial in quite a similar way the recognition and enforcement of foreign criminal judgments resembles, differs from and substitutes the extradition for punishment (the conviction extradition).

Both the extradition for punishment and the recognition and enforcement of foreign judgments support the completion of criminal justice by securing the convict for the execution of the punishment imposed on him/her. However, this result is achieved in the opposite ways. In the case of extradition, the result is 
achieved by bringing the sentenced person to the punishment (in the country of the criminal and execution proceedings) while in the case of the recognition and enforcement of foreign judgments the result is achieved oppositely, namely: by carrying the punishment to the sentenced person (to the country of his/her residence). Yet, given that both the extradition for punishment and the recognition and enforcement of foreign judgments put together the sentenced person and the punishment, they are distinguishable from the transfer of sentenced persons (prisoners, actually) where this result does not occur. In the common case of such transfer, the sentenced persons have been available for the prosecution and trial against them and also for the imposition and execution of the punishments imposed on them. This is why it is not necessary, at all, to put together the sentenced persons and the punishments $[1,2]$.
Further on, both the extradition for punishment and the recognition and enforcement of foreign judgments, usually, are based on an agreement or reciprocally. Both modalities of international judicial cooperation are requested on behalf of the interested country rather than the magistrate (prosecutor or judge/court) in charge, as it is in the case with letters rogatory. Each of these modalities requires applicability of the requesting country's criminal law to the crime for which the punishment was imposed. Dual criminality is the key prerequisite of both modalities. Dual punishability of the alleged offender (not excluded by any amnesty, pardon or lapse of time) is also needed for both of them. His/her provisional detention is allowed to secure his/her future presence. Full detention follows in both cases when the formal request is received. Lastly, the channels of communications are similar [3].

\section{Extradition for Execution of Punishment - vs. - Recognition and Enforcement of a Foreign Judgment (general comparison)}

\begin{tabular}{|c|c|c|}
\hline COMMON FEATURES & \multicolumn{2}{|c|}{$\begin{array}{l}\text { Serve justice by putting the convict and the punishment together. Resorting to each of } \\
\text { them is a matter of the interested country's discretion. }\end{array}$} \\
\hline & \multicolumn{2}{|c|}{ Dual criminality required } \\
\hline & \multicolumn{2}{|c|}{$\begin{array}{l}\text { Final enforceable sentence with minimal punishment, involving deprivation of liberty, } \\
\text { exist }\end{array}$} \\
\hline & \multicolumn{2}{|c|}{ The enforcement proceedings in the execution country are governed by its national law } \\
\hline DIFFERENCES & $\begin{array}{l}\text { EXTRADITION FOR EXECUTION } \\
\text { OF A PUNISHMENT }\end{array}$ & $\begin{array}{l}\text { RECOGNITION \& ENFORCEMENT } \\
\text { OF A FOREIGN JUDGMENT }\end{array}$ \\
\hline CHANGE IN THE & The convict is brought to the punishment & The punishment is carried to the convict \\
\hline DESTINATION & $\begin{array}{l}\text { They are put together in the country, } \\
\text { where the punishment was imposed }\end{array}$ & $\begin{array}{l}\text { They are put together in the country, where } \\
\text { the convict resides }\end{array}$ \\
\hline RELEVANCE OF NATIONALITY & $\begin{array}{l}\text { 1. Usually, the convict's nationality of } \\
\text { the requested country constitutes an } \\
\text { impediment. } \\
\text { 2. The convict's nationality of the } \\
\text { requesting country is not a condition. }\end{array}$ & $\begin{array}{l}\text { 1. The convict's nationality never constitutes } \\
\text { impediment. } \\
\text { 2. The convict's nationality of the requested } \\
\text { country is a typical condition. }\end{array}$ \\
\hline TRANSFER OF COMPETENCE & No transfer of competence takes place & $\begin{array}{c}\text { Transfer of competence for enforcement of } \\
\text { the foreign country's } \\
\text { Sentence takes place }\end{array}$ \\
\hline $\begin{array}{l}\text { APPLICABILITY OF THE } \\
\text { SPECIALITY RULE, WHEN THE } \\
\text { REQUEST IS GRANTED }\end{array}$ & $\begin{array}{l}\text { The extraditee enjoys personal immunity } \\
\text { in the Requesting country as it is bound } \\
\text { by the Speciality Rule }\end{array}$ & $\begin{array}{l}\text { The convict does not enjoy any personal } \\
\text { immunity as the Requested country is not } \\
\text { bound by any Speciality Rule }\end{array}$ \\
\hline
\end{tabular}

In Europe, the recognition and enforcement of foreign criminal judgments are governed in detail by the European Convention on the International Validity of Criminal Judgments. According to its Article 64 (2), the Convention constitutes the primary legal framework for the transfer to its Parties. The other agreements between them provide the subsidiary rules.

\section{The Prerequisites and the Procedure}

Most often, as in the case with the transfer of criminal proceedings, the recognition and enforcement of foreign criminal judgments requires (i) an international agreement or reciprocity, (ii) the applicability of the requesting country's criminal law to the criminal offence for which the punishment was imposed and also (iii) dual criminality of this offence. However, the applicable Somali law is different.
First of all, Article $10(2,3)$ of the PC requires extradition agreement with the requesting (sentencing) country or permission of the Somali Minister of Grace and Justice for the institution of proceedings in Somalia for the recognition and enforcement of the criminal judgment of the other country.

Secondly, no express requirement exists that Somali penal law (the PC or a special penal law) shall be applicable to the criminal offence for which the punishment was imposed in the other country.

Thirdly, it is not clearly required either that the offence is a crime not only under the law of the other country but also under Somali law as well. 
By virtue of Article 10 (1) of the PC, the foreign judgement may be recognized: (a) to establish that the offender is a recidivist or to establish any other penal consequence of a conviction, or to pronounce that the offender is a habitual or professional delinquent; (b) if the conviction would involve an accessory penalty, according to Somali law; (c) if according to Somali law, the person convicted or acquitted would be liable to security measures in case he was in the territory of the Somalia or (d) if the foreign judgment orders restitution or compensation for damages ...

As in the case with the transfer of criminal proceedings, the recognition and enforcement of foreign criminal judgments need some link between the sentenced person and Somalia as the requested country. According to Article 282 (1) of the CPC, the person must be a Somali national orone who resides in Somalia (namely: a foreign or a stateless person).

Similarly to the transfer of criminal proceedings, the existence of a final judgment on the person for the same offence in the requested country shall inevitable be a mandatory impediment to the recognition and enforcement of foreign criminal judgment [the Non-bis in idem principle]. Finally, such an impediment is the unacceptability of the foreign judgment on the grounds that it ,contains any provisions which are contrary to, or incompatible with, any provision of the Constitution of the Somali Republic or any of the general principles of the law of the State" - Article 285.1 (c) of the CPC.

In many foreign countries, the person concerned may be placed under provisional detention up to 18 days in the requested country until the request for the recognition of the foreign judgment arrives. To this end a petition for the detention by the requesting country is necessary. The petitioning country must expressly announce in it its intention to request the petitioned country for recognition and enforcement of its judgment - see e.g. Article 32 (2) of the European Convention on the International Validity of Criminal Judgments.

This is detention similar to the provisional extradition detention (Article 279.2 of the CPC) as both are justified by the need to prevent the person from escaping justice and punishment. Such provisional detention pending the request for the recognition of the foreign judgment and imposed for the purposes of securing the execution of the punishment imposed makes sense in Somalia also. In view thereof, its reception in the $\mathrm{CPC}$ (BOOK FIVE) is recommendable.

In Europe, provisional detention may be petitioned, in particular, for any sentenced foreigner who seeks to avoid the execution or further execution of the punishment by fleeing to the territory of his own country before having served the punishment in the sentencing country. In such cases, the sentencing country may request the other country to take over the execution of the punishment. Before the arrival of the documents supporting the request and/or prior to the decision on it, the sentencing country may send a petition for the provisional detention of the sentenced person, pending a decision on the request.

Although this specific cooperation is regulated by the Additional Protocol to the Convention on the Transfer of Sentenced Person (Article 2), it is, actually, also recognition and enforcement of foreign criminal judgments. In contrast to the actual transfer, which does not directly support criminal justice as the person and the judgment against him are not separated, in the cases envisaged by Article 2 of the Additional Protocol they are separated. The judgement must be 'brought' to the sentenced person in order to reach the goal of actual execution of the punishment imposed.

Exceptionally, if the convict is, for any reason, in the territory of the sentencing country after the approval of the request by the other country, the authorities of the sentencing/requesting country may detain him/her in order to surrender him/her to the requested country, which has already decided to execute the punishment imposed on him/her. No petition for the detention is necessary in this case. (Articles 31 and 43 of the aforementioned European Convention).

Actually, such a surrender constitutes extradition for punishment. This is why the person if surrendered, enjoys the immunity of an extraditee in the other country: s/he is protected by the Speciality Rule and cannot be prosecuted, trialled and/or punished for any other crime committed before the surrender - see Article 9 of the European Convention.

The incoming request for the recognition and enforcement of the foreign criminal judgment shall be addressed to the Somali Minister of Grace and Justice. In turn, s/he shall transmit the request to the Attorney General together with a certified copy of the judgment together and all related documentation (Articles 282.1 and 284.2 of the CPC). If necessary, the Attorney General may require through the Minister of Grace and Justice additional information about the conviction from the requesting country - Article 282.2 (ii) of the CPC.

If the Attorney General agrees with the foreign request, he shall make a proposal to the President of the Court of Appeal within whose jurisdiction the Criminal Records office is located to grant the request (282.2 of the CPC). The President of the Court of Appeal shall decide whether the judgment shall or shall not be recognized. The Attorney General may appeal against the decision to the Supreme Court (285.2 of the CPC). 
The Consequences of the Recognition and Enforcement of the Foreign Judgment

The Granted Recognition and Enforcement (approval of the outgoing request by the requested foreign country)

If the request is approved, the requesting country relinquishes competence over the execution of the punishment. This is why it shall terminate its enforcement proceedings. However, if the punishment is not executed in the requested country, the requesting country retakes competence and the right of execution of the punishment reverts to its competent authorities see Article $11(2, \mathrm{c})$ of aforementioned Convention. In Europe, this country may exercise the right of amnesty or pardon with regard to the convict; it alone has the right to decide on any application for extraordinary review of the sentence - see Article $10(2,3)$ of the Convention.

At the same time, the requested country acquires competence over the execution of the punishment. This is why its authorities initiate own enforcement proceedings, which shall be governed by their national law (Article 10 of the European Convention). An adaptation decision is to be rendered in accordance with it - see e.g. Article 26 (5) of the Turkish Law on International Judicial Cooperation in Criminal Matters. Any part of the punishment previously served in the requesting country or in any third country, as well as any security measure in the form of detention in relation with the crime for which the transferred punishment was imposed, shall be credited towards the adapted punishment in the requested country - see e.g. Section 54 (4) of the German Law on International Judicial Cooperation in Criminal Matters.

Also, the court of this country may replace the custodial sentence by a penalty of another nature and of different duration, as provided for in its law for the same offence. The penal situation of the person shall never be aggravated (Article 44 of the same Convention). In Europe, this country may also exercise the right of amnesty or pardon with regard to the convict and can grant him/her conditional release but has no authority to review the foreign sentence - see Article 10 of the European Convention).

\section{The Recognition and Enforcement rejected}

If the request is rejected, the requesting country retains competence over the enforcement and its right of execution of the punishment. The requested country does not acquire any such competence.

It is also possible, after having granted the request, the requested country to relinquish its right of enforcement, if also: both countries agree on this or the enforcement is no longer possible in its territory. In this situation, the requesting country retakes competence over the execution of the punishment.

Transfer of Criminal Proceedings - vs. - Execution of a Request for Institution of Criminal Proceedings against a National of the Requested country

\begin{tabular}{|c|c|c|}
\hline COMMON FEATURES & \multirow{2}{*}{\multicolumn{2}{|c|}{$\begin{array}{l}\text { Serves justice by ensuring criminal proceedings in the requested country against } \\
\text { an alleged offender } \\
\text { Dual criminality is required }\end{array}$}} \\
\hline & & \\
\hline & \multicolumn{2}{|c|}{$\begin{array}{c}\text { The criminal procedure law of the requesting country is never applicable to criminal } \\
\text { proceedings in the requested country }\end{array}$} \\
\hline & \multicolumn{2}{|c|}{ The alleged offender is always known } \\
\hline & \multicolumn{2}{|c|}{$\begin{array}{l}\text { If the request is granted, the Requested country is not bound by any Speciality Rule; as a } \\
\text { result, the person (suspect/indictee) does not enjoy any immunity there }\end{array}$} \\
\hline DIFFERENCES & Transfer of Criminal Proceedings & $\begin{array}{l}\text { Execution of a Request for } \\
\text { Institution of Criminal Proceedings } \\
\text { against a National of the Requested } \\
\text { country }\end{array}$ \\
\hline LEGAL GROUNDS & $\begin{array}{l}\text { It is based on different agreements (multilateral } \\
\text { conventions and bilateral treaties) }\end{array}$ & It is based on bilateral treaties, mostly \\
\hline $\begin{array}{l}\text { RELEVANCE OF } \\
\text { NATIONALITY }\end{array}$ & $\begin{array}{l}\text { The suspect/indictee is not necessarily a national } \\
\text { of the requested country }\end{array}$ & $\begin{array}{l}\text { The suspect/indictee must be a national } \\
\text { of the requested country }\end{array}$ \\
\hline $\begin{array}{l}\text { TRANSFER OF } \\
\text { JURISDICTION }\end{array}$ & $\begin{array}{l}\text { Relinquishes the jurisdiction over the case to the } \\
\text { requested country }\end{array}$ & $\begin{array}{l}\text { Does not relinquish any jurisdiction } \\
\text { over the case to the requested country }\end{array}$ \\
\hline $\begin{array}{l}\text { ADMISSIBILITY OF } \\
\text { COLLECTED EVIDENCE }\end{array}$ & $\begin{array}{l}\text { The admissibility of evidence, collected in the } \\
\text { requesting country, is preserved in the requested } \\
\text { country, once it takes charge of the case }\end{array}$ & $\begin{array}{l}\text { The evidence, collected in the } \\
\text { requesting country, is not admissible in } \\
\text { any proceedings of the requested } \\
\text { country }\end{array}$ \\
\hline $\begin{array}{l}\text { BINDING EFFECT OFTHE } \\
\text { FOREIGN COUNTRY'S } \\
\text { CRIMINAL LAW }\end{array}$ & $\begin{array}{c}\text { In its proceedings, the requested country may be } \\
\text { bound by some rules of the requesting country's } \\
\text { criminal law - in cases of a derivative (given) } \\
\text { jurisdiction }\end{array}$ & $\begin{array}{l}\text { In its proceedings, the requested } \\
\text { country is never bound by any rule of } \\
\text { the requesting country's criminal law }\end{array}$ \\
\hline
\end{tabular}


The Necessary Recognition and Enforcement of the Foreign Judgment in Cases of Import Transfer of Prisoners

Prisoners, who are foreign nationals, may be handed over to the countries of their nationalities to serve the unexecuted part of their imprisonment punishment there. They were sentenced abroad but they, the sentencing country and their home country have all agreed that the execution of the judgment should be finalized at home. The judgment is also recognized and where necessary, adapted to the penal system of the receiving country, which takes charge of administering the unexecuted part of the punishment, e.g Section 54 of the German Act on International Judicial Cooperation in Criminal Matters and Article 611 of the Ukrainian CPC. The recognized judgment has a legal force and effect equal to those of judgments issued in the administering country - see Article 461 of the Bulgarian CPC and Article 71 (1) in conjunction with Article 68 (4) of the Bosnian Law on International Judicial Cooperation in Criminal Matters, for example. This is why, given the NE BIS IN IDEM principle, this administering country cannot issue another, own judgment for the same crime against the same offender, the transferee. However, it can prosecute, detain, try and punish him/her for other crimes as this country is not bound by any 'speciality rule' as in the cases of extradition [4].

Also, the significance of the nationality of the person concerned is different. Most countries do not extradite own nationals, e.g. Article 35.2 of the Somaliland Constitution. In contrast to extradition, the person may always be transferred, even if s/he is a national of the surrendering country. It would be sufficient that the person is a national of the country, which takes him/her over to complete the enforcement of the surrendering country's judgment $[5,6]$.

Unlike both, extradition for punishment execution and recognition and enforcement of foreign judgments, the convict and the punishment on him/her are not separated, initially, and do not need to be brought together for the execution of this punishment. In the case of prisoner transfer, the convict and the punishment are both at the disposal of the sentencing country, which gives them both to the country of the person's nationality.

\section{MODALITIES OF INTERNATIONAL JUDICIAL COOPERATION - COMPARISON \\ Modalities that BRING TOGETHER the} person and the proceedings, as they have been separated, initially:

1. The prosecuted person and the criminal proceedings against him/her:

1.1 by carrying the person to the proceedings - EXTRADITION FOR TRIAL [not accompanied by a transfer of any jurisdiction], or

1.2 by carrying the proceedings to the person - TRANSFER OF CRIMINAL PROCEEDINGS [involves a transfer of jurisdiction];

2. The sentenced person and the punishment against him/her:

1.1 by carrying the person to the punishment (the execution proceedings) CONVICTION EXTRADITION [not accompanied by a transfer of any competence], or

1.2 by carrying the punishment (the execution proceedings) to the person RECOGNITION AND ENFORCEMENT OF A FOREIGN CRIMINAL JUDGMENT [involves a transfer of a competence].

A modality that TRANSFERS TOGETHER, as unseparated initially, both the sentenced person and the punishment (the execution proceedings) against him/her to the country of his/her nationality - TRANSFER OF A SENTENCED PERSON (PRISONER) - involves a transfer of competence.

As all parties involved agree on the transfer, it creates fewer problems than extradition, for example [7]. In general, the country of the transferee shall apply its law to the execution of the unserved part of the punishment [8], honouring the prior applicability of the sentencing country's law to this part of the punishment, which has been already served in that country before the transfer.This means that even if the administering country's law is more lenient, it shall not be applied retroactively for the benefit its transferred national, e.g. to reduce the punishment on grounds, provided for in the administering country's law, if no such rule existed in the sentencing country.Thus, the executing country shall not be permitted to grant to any transferee reduction in the imprisonment punishment by reason of work s/he carried out during the period of his/her detention in the sentencing country, if no such reduction was granted by the competent authorities there in accordance with their law [9].

The administering country is not allowed to review the foreign judgment, let alone change it. This is a common principle - Article VIII (sentence 1) ofthe Inter-American Convention on Serving Criminal Sentences Abroad, Article 13 (2) of the British Commonwealth Scheme for the Transfer of Offenders, Article 13 of the European Convention on the Transfer of Sentenced Persons, Article 5 of the Memorandum of Understanding betweenSomaliland andSeychelles on the Transfer of Sentenced Pirates, etc. 
The applicability of the administering country's law to the execution of punishment on the transferee is not an absolute rule. Its application might be restricted. For example, by virtue of Article 61 (2) of the 1983 Riyadh Arab Agreement for Judicial Cooperation(ratified by Somalia on the 21 st of October 1985), the administering country's law on pardon is not applicable.

The issue of pardoning is delicate and contentious in some cases. Recently, on 29 July 2019, the Somaliland President pardoned 19 pirates who had been sentenced in Seychelles and later, transferred to Somaliland [SL]. He referred to his constitutional right to grant pardons under Article 90.5 of the SL Constitution in conjunction with Article 7 (2) of the aforementioned Memorandum of Understanding $[\mathrm{MoU}]$, which reads: "The continued enforcement of the sentence after transfer shall be governed by the laws and procedures of the receiving State or Authority..." [10] Some international experts disagreed with this act of the SL President. They argued that the President had no right under Article 7 (2) of the MoU to pardon and by pardoning the sentenced pirates, he eventually, violated the $\mathrm{MoU}$.

Indeed, one should agree with such a critical evaluation if $\mathrm{s} / \mathrm{he}$ accepts the European model of regulating the issue. Pursuant to Article 12 (i) of the Convention on the Transfer of Sentenced Person, "Each Party may grant pardon ... in accordance with its Constitution or other laws". However, Somalia, including SL, does not adhere to the European international treaties model of using explicit concretizing permission to the administering country for pardoning transferees.

As a Party to the Riyadh Arab Agreement for Judicial Cooperation, Somalia, incl. SL, follows the opposite international treaties model (Arab, British and American). Under it, the lack of any prohibition in the treaty to the receiving country for pardoning is sufficient. Should, however, this country be prevented from pardoning transferees, an explicit disallowing prohibition in this sense is necessary for the respective treaty with the sentencing country. Such necessary disallowing provisions are, in addition to the abovementionedArticle 61 (2) of the 1983 Riyadh Arab Agreement for Judicial Cooperation, also Article 13 (1) ofthe British Commonwealth Scheme for the Transfer of Offenders and Article VIII (sentence 2.1) of the Inter-American Convention on Serving Criminal Sentences Abroad. As no such disallowing rule exists in the MoU, critics against the SL President seem unfounded [11].

Finally, Somalia may grant amnesty to its nationals transferred as prisoners to its territory under the Riyadh Arab Agreement for Judicial Cooperation (Articles 58 - 63). Some conditions should be met, though. Thus, according to Article 61 (3 and 4) of this Agreement, if a general amnesty issued by the administering Party includes the transferee, this Party shall notify the sentencing one, "which may request that the convict be returned to it to serve the remaining period of his sentence. If no such request is submitted within 15 days of the date of notification, it shall be deemed that the Party concerned has disregarded the recovery of the said person, in which case the general amnesty shall apply to him".

Detentions in Relation to Incoming Requests for Recognition and Enforcement of Foreign Judgments

If Somalia grants such an incoming request, its authorities may detain the convict to secure the enforcement of the recognized foreign criminal judgment against him/her. Article 285 (4) provides some legal basis for his/her detention after the court proceedings. This Paragraph 4 reads as follows: „If no mention is made in the decision allowing recognition of the judgment with regard to anything that may be done as a result of such decision and if no mention is made regarding any security measures which may be applied, the President of the Court may order such provisions later, upon the request of the Attorney General, following the procedure for matters arising in execution".

The problem is that no such measures against the person (including his/her detention) exist for the time period of the court proceedings, let alone before them, although s/he often has the interest in running away during the court proceedings and even before them. This legislative gap may create serious difficulties, sometimes. In view of thereof, it is the introduction of such measures in the CPC is worth considering. The Council of Europe Conventions in the penal field might be used as examples.

Thus, according to Articles 32.2 and 33.2 (b) of the European Convention on the International Validity of Criminal Judgments, any Party may put the person, found in its territory, under provisional arrest for 18 days pending the official request of another Party for the recognition and enforcement of its criminal judgment, issued against him/her. To this end, the interested other Party shall forward a separate application for such arrest. As per Article 32.2 (ii) of the Convention, "The said application shall state the offence which led to the judgment and the time and place of its perpetration, and contain as accurate a description as possible of the person sentenced. It shall also contain a brief statement of the facts on which the judgment is based".

After that, once the official request is received, the requested Party shall hold the person in full arrest (detention) in accordance with its law. The law of that Party "shall also determine the conditions on which he 
may be released" - Article 33.1 of the same European Convention.

\section{Foreign Criminal Judgments Which Do Not Need Recognition and Enforcement}

According to Article 9 of the Somali PC, "Apart from the cases specified in article 7, criminal proceedings for a crime committed abroad cannot be instituted against a person who was finally acquitted abroad of the same crime or against a person who, abroad, has been convicted of a(the same, actually) crime and has served the sentence prescribed, therefore". This general rule obliges the Somali judiciary to accept all foreign judgments regardless of their reliability. However, the reliability factor shall not be ignored. It must be taken into account as in most other contries. To this end, it would be wise to narrow the scope of Article 9 of the PC that any foreign judgment impedes the prosecution, trial and punishment of the person trialled abroad. Otherwise, Somalia shall trust all foreign judiciaries (over 200 in the world), in full and unconditionally, and shall accept each of their judgments like its own. Hence, if the aforementioned general rule of Article 9 of the PC stays, Somali authorities would not be allowed to question as to whether the person has not been shielded by the judiciary in the foreign country, especially if s/he was acquitted, or whether the punishment imposed on him/her was not too lenient. To avoid such unacceptable restrictions, e.g. Article 9 of the Turkish PC postulates, contrary to Article 9 of the Somali PC, that ,A person who is convicted in a foreign country for an offence committed in Turkey is subject to retrial in Turkey". Unless the foreign judgment has been recognized on some grounds (see Articles 282-286 CPC and 10 of the PC), the general rule is that such a judgment constitutes no impediment to criminal proceedings against the same person for the same crime(s). This rule is clear and easy to apply. Certainly, this rule is restricted in some countries, e.g. Articles 5 and 7 of the Libyan PC but at this point, such further complications should not be necessarily supported.

In view thereof, it might be recommended that the non-recognized foreign judgment does not preclude the institution of criminal proceedings. However, any foreign deprivation of liberty (pre-trial and trial detention or/and punishment) in relation to it, shall always be deducted from the punishment imposed in Somalia, if any. Such a rule would preserve the positive element in Article 9 of the Somali PC that the convict shall not serve again what $\mathrm{s} / \mathrm{he}$ has already served in the sentencing country.

Moreover, such a rule already exists to the necessary extent in Article 115 of the Somali PC. Its applicability is not excluded with regard to the situations when criminal proceedings have been instituted despite the existence of a foreign judgment for the same crime of the same person. This Article 115 reads: "Where a person tried abroad is again tried in the territory of the State, the punishment served abroad and the nature thereof shall be taken into account...".This Article presupposes that and, actually, makes sence only if Somali criminal proceedings are allowed for the same crime and against the same person. Otherwise, nothing can be taken into account, including already served punishment, if no such proceedings are launched.

It is notewothy that Article 5 of the Japanese PC provides an interesting example of treating foreign criminal judgments:

„Even when a final and binding decision has been rendered by a foreign judiciary against the criminal act of a person, it shall not preclude further punishment in Japan with regard to the same act; provided, however, that when the person has already served either the whole or part of the punishment abroad, execution of the punishment shall be mitigated or remitted. Article 5 Even when a final and binding decision has been rendered by a foreign judiciary against the criminal act of a person, it shall not preclude further punishment in Japan with regard to the same act; provided, however, that when the person has already served either the whole or part of the punishment abroad, execution of the punishment shall be mitigated or remitted."

Finally, as a compromise it might be accepted, in addition, that the foreign penal judgment constitutes an impediment to instituting criminal proceedings for the same case, also if the competent Somali authorities find that the judicial system of the sentencing foreign country has been fully reliable in handling the case. Certainly, such an additional rule might be reduced to criminal cases in reliable countries where no punishment on the convict is enforceable by the time of the Somali decision on the institution of the respective criminal proceedings - see as an example Article 53 of the European Convention on the International Validity of Criminal Judgments. Such impediments to instituting criminal proceedings in Somalia might be the criminal cases where:

- The foreign criminal judgment acquits the person, or

- The person is found guilty but, in accordance with the sentencing country's law, no punishment was imposed on him/her, or although imposed, this punishment is no longer enforceable as it was served in full or has extinguished because of lapse of time (statute of limitations), pardon or amnesty.

Article 40 (2) of the 2015 Puntland Sexual Offences Act, which also regulates the consequences of foreign criminal judgments, raises some further questions. It reads as follows: "A person may not be convicted of an offence contemplated in sub-section (1) if such a person has been acquitted or convicted in the country where that offence was committed." This 
provision narrows the scope of Article 9 of the PC by requiring that the foreign judgment should be necessarily, issued in the country of the commission of the sexual offence. Per argumentum a contrario, if a judgment has been issued in a third country only (e.g. the country of the injured party's/victim's nationality) this would be no impediment to the prosecution, trial and punishment of the person.

However, there is no justification for preferring the country of commission to all other, third countries. The third country may have been, sometimes, in a position to collect more evidence (e.g. because the offender was also its national) than the country of the commission of the sexual offence. Besides, the third country may have been much more reliable when it comes to abiding by the rule of law principle. Moreover, the country of the commission might be so unreliable that Somalia would never recognize and enforce any of its judgments - Article 10 of the PC and Articles 282-286 of the CPC. Per argumentum a fortiori, judgments issued in such a country should not prevent Somali judicial authorities from giving own justice. Hence, the place of commission cannot be any criterion. The acceptable criterion should be whether the country, where the judgment was issued, has a reliable criminal justice system. Only if it has, the Somali judicial authorities should be impeded by the judgment issued there.

\section{Recognition and Enforcement of Foreign Confiscation Orders \\ The foreign judgment may contain a} confiscation order for a property, which in whole or in part is located in the territory of the requested country. Such an order may also exist and be sent separately for recognition and enforcement.

Somalia still adheres to the traditional confiscation. It is a security measure in respect of property. It is regulated by Article 183 of the PC, which reads as follows:

"On a conviction, the Judge may order the confiscation of the material objects which were used or intended to be used in the commission of the offence [15 P.C.], or of those which are the proceeds or the profits thereof.

\section{Confiscation shall be ordered:}

a) Of material objects which constitute the rewards for the offence [15 P.C.];

b) Of material objects whose manufacture, use, possession, custody or alienation constitutes an offence [15 P.C.], evenwhere no conviction was pronounced...".

Hence, the confiscatable assets of the offender shall be related to his/her proven crime (being its object, instrumentality or/and gain), regardless of whether or not a conviction was pronounced.Also, the Somali law requires that the existence of such property and its link to the crime has been proven with the same high evidentiary standard ["beyond a reasonable doubt"] as the crime itself.

Given the necessary connection with the proven crime, this confiscation is designated as 'criminal'. This is why courts in Somalia and other countries with this traditional form of confiscation do not confiscate from the owner any of his/her assets if their link with the crime is not proven like the crime itself or his/her assets originate from other criminal activities (his/her or another person's), even if a proven link between them and the activities exists.

However, there are foreign countries, which follow other models of criminal confiscation with looser requirements. The confiscatable property under these models is larger in volume.

The first of them is the extended confiscation. It has been introduced in Bosnia and Herzegovina (see below), Romania (Article 112-1 of its Criminal Code), Serbia (Article 3.2 and 28.2 of its Law on Seizure and Confiscation of Proceeds from Crime) and some other countries as well. Such countries confiscate not only the assets, which derive from the crime for which the owner has been convicted. These countries also confiscate assets originating from any other criminal activities, if some evidence of a link between them exists. In any case, a lower evidentiary standard of proving the link is sufficient. Thus, according to Article 110a (1) of the Bosnian Criminal Code, there must be "sufficient evidence to reasonably believe that the property gain is of criminal origin". Article 114a of the Criminal Code of the Federation of Bosnia and Herzegovina (one of its entities) is similar. It reads that ,the court can also ... order confiscation of material gain for which the prosecutor provides sufficient evidence that there is reasonable suspicion that it was acquired through ... criminal offences...".

So, some vague causal link with criminal activities is required; a suspicion that the property of the convict (his/her non-reported/ unlawful property) is of criminal origin. In practice, any evidence is sufficient. Thus, in contrast to criminal proceedings, where the crime of the accused must be proven beyond a reasonable doubt (say: 95+), in the extended conviction procedure the level of proof should be as lower one as in any other civil proceedings, namely: the plaintiff/claimant must prove his/her case by a preponderance of the evidence $(50 \%+)$. As a result, the defendant, who is the target property owner as well, is interested in seeking and presenting own pieces of proof to oppose/ neutralize the existing evidence against him/her. 
The other type of new confiscation is the socalled unexplained wealth confiscation. It implies a larger volume of confiscation; its volume is larger even compared to the previous group.

The unexplained wealth confiscation also needs a conviction but does not require any link with criminal activities at all. Therefore, the prosecutor shall not prove that the property claimed for confiscation derives from any criminal activity. This type of confiscation has been introduced in Bulgaria (see below), Italy (Article 240-bis of its Penal Code), Ukraine (Article 100.9.6-1 of its CPC), the UK (Articles 362a-362t of the UK Proceeds of Crime Act) and some other countries.

Thus, the Bulgarian 2018 Law on Combating Corruption and Forfeiture of Illegally Acquired Property, Chapters X - XIII, requires a final judgment, in general. However, in some cases, confiscation is achievable even if criminal proceedings against the suspected owner have not been instituted at all or after their initiation, have been terminated or suspended Article 108 of the Law. Lastly, as the focus on this confiscation is the property of the person, his/her assets may be confiscated, in some cases, even when s/he is acquitted if no evidence of their legal origin has been presented by him/her.

The Albanian Antimafia Law (No. 9284 of 2004 "On Preventing and Striking at Organized Crime") is similar. Pursuant to its Article 24 (1), confiscation shall be imposed when there are reasonable doubts that the person participated in organized criminalactivities and it has not been proven that his/her assets have a legal origin or the s/he did not manage to justify the possession of assets, disproportionate with his/her incomes or profits gained through legal resources declared by him/her.

No doubt, a country, using any of these two modern forms of confiscation, may turn to Somalia. This is why the Somali legislation must decide whether to grant incoming requests for recognition and enforcement of such confiscation orders, which do not meet the strict standards of traditional confiscation under Article 183 of the PC. In case of a positive legislative decision, whereby such orders are also recognizable and enforceable in Somalia, this, in turn, would open the way to Somali authorities to reciprocally request these countries for recognition and enforcement of orders for confiscation of assets, found in their territories, even when the Somali own standards have not been met.

Another problem to be addressed by the Somali legislation is the so-called Civil Forfeiture [12]. It is a confiscation without any criminal judgment at all. Following the recommendation of Article 54.1, letter "c" of the UN Convention against Corruption [13], some foreign countries do not require any longer criminal conviction as a prerequisite to obtaining an order of confiscation, especially in cases when the perpetrator enjoys immunity or s/he has died or fled and cannot be trialled in absentia [14]. Somalia is not among those countries yet. Because of this difference, the Somali legislation needs to decide whether incoming requests form such foreign countries for civil forfeiture (non-conviction based confiscation) may be granted and when, despite its present inapplicability in Somalia.

It would be particularly important to clarify in all cases whether Somali authorities would render nottreaty based cooperation to foreign countries for confiscation. Since Somalia is a Party to very few international agreements and is not expected to have much more agreements with other countries, not-treaty based cooperation would also be recommendable.

Finally, it is to be remembered that national confiscation mechanisms are usually triggered when the respective crime is within the criminal jurisdiction of the country as its penal law is applicable to this crime. However, foreign countries may request confiscation of proceeds found in Somalia that derive from crimes, which are beyond the reach of the Somali penal law. Such a legislative gap shall not be allowed. It can be excluded by an explicit rule that confiscation mechanism of Somalia shall be also applicable when the incoming request for confiscation concerns proceeds, deriving from crimes, which are beyond the reach of the Somali penal law.

\section{CONCLUSION}

The mutual recognition of criminal judgments and other judicial decisions, especially for constraint and confiscation of crime proceeds, is one of the principles of contemporary international judicial cooperation in criminal matters. This principle is implemented mainly through two of the modalities of international judicial cooperation, namely: recognition and enforcement of foreign criminal judgments as well as the transfer of prisoners, as it necessarily involves recognition and enforcement concerning the judgment against them in the sentencing country. The international efforts to fight crime would not be efficient if countries do not make use of these two modalities of international judicial cooperation. Weaker countries, such as Somalia, should be supported and encouraged in developing these modalities. Also, such countries should be made more visible and predictable in making use of them. Serious work must be done to improve the Somali law on confiscation, including international cooperation in this area.

\section{REFERENCES}

1. International Criminal Law. (2008). Volume II: Multilateral and Bilateral Enforcement, edited by 
M. Cherif Bassiouni, 3-rd ed, Martinus NIJHOFF, Leiden, 512.

2. Zgonec-Rozej, M. (2010). International Criminal Law Manual, International Bar Association, London, 374.

3. Voynova, R. (2015). Comparison of the transfer of criminal proceedings with other forms of international legal cooperation in criminal matters, in: scientific collection "The complex physiognomy of the international security environment", LF Academy "Nicolae Balchesku", Sibiu (Romania), 178.

4. Bernacchi, M. B. (1992). Standing for the Doctrine of Specialty in Extradition Treaties: A More Liberal Exposition of Private Rights, Vol. 25, No. 4, LOY. L.A. Int'1 \&Comp. Law Review, p. $1377 . \quad$ Available at: https://digitalcommons.lmu.edu/llr/vol25/iss4/ 15/, accessed on 12 May 2019.

5. Thus, according to Point 20 (2) of the Explanatory Report to the Convention on the Transfer of Sentenced Persons [Council of Europe, 1983], "It is not necessary for the person concerned to be a national of only the administering State. The Contracting States may decide to apply the convention, when appropriate, in cases of double or multiple nationalities even when the other nationality (or one of the other nationalities) is that of the sentencing State. It is to be noted, however, that even where all the conditions for transfer are satisfied, the requested State remains free to agree or not to agree to a requested transfer. A sentencing State is, therefore, free to refuse a requested transfer if it concerns one of its nationals".

6. Girginov, A. (2015). Foreign Nationals and Criminal Justice (The Case of Iraq), in "Uyusmazlik Mahkemesi Dergisi [Turkish: Journal of the National Court of Jurisdictional Disputes]", Ankara, No. 5, 444.

7. Plachta, M. (1993). Human Rights Aspects of the Prisoner Transfer in a Comparative Perspective, Louisiana Law Review, Vol. 53, No. 4, p. 1043. Available at: https://digital commons.law.lsu.edu/lalrev/vol53/iss4/3, accessed 8 August 2019.
8. Handbook on the International Transfer of Sentenced Persons, UNODC, New York, 2012, 51.

9. Vermeulen, G. W., De Bond, W. (2017) Justice, Home Affairs and Security. European and International Institutional and Policy Development (second revised edition), Maklu /Antwerp/ Apeldoorn, 96.

10. Somaliland Standard news agency of August 2, 2019. Available at http://somaliland standard.com/somaliland-bids-farewell-to-19pirates-from-somalia-after-serving-9-years behindbards/, accessed on 7 August 2019.

11. Moreover, it is solely the SL state authorities, which are empowered to officially interpret their Constitution and the $\mathrm{MoU}$ in such cases. They found that the President granted pardon on the basis of the Constitution and in conformity with the MoU; this MoU confirmed the Constitutional provision, which establishes the power of the President to pardon the transferees. But even if the SL Constitution were in conflict with the MoU, this MoU cannot prevail over the Constitution. Actually, it would be the other way around, namely: the Constitution would override this MoU [Benvenisti and Harel, 2017]. As a result, only the SL Constitution would be applicable to eventually preserve the President's power to grant pardon. Being inapplicable, the MoU cannot be violated.

12. Gowtzke, T. J. (2010). Conviction or Confiscation. The Introduction and Implementation of the NonConviction Based (NBC) Confiscation in the European Union. A Comparative Analysis. BSc Diss. The University of Portsmouth.

13. This provision expressly requires from the State Parties to "consider taking such measures as may be necessary to allow confiscation of ... property without a criminal conviction in cases in which the offender cannot be prosecuted by reason of death, flight or absence or in other appropriate cases".

14. Block-Lieb, S., \& Halliday, T. C. (2006). How Global Law-Making Is Possible: Legitimation Strategies and Rule Production in the UNCITRAL Legislative Guide on Insolvency Law. Working Paper, American Bar Foundation. 